\title{
NATIONAL INTEREST VS. ONLINE FREEDOM OF EXPRESSION: THE DISCUSSIONS OF INTERNET USERS ON THE BLOCKING OF 'WIKIPEDIA' IN TURKEY
}

\author{
Ruhdan UZUN*
}

Received: 15.01.2020 - Accepted: 04.03.2020

Uzun, R. (2020). “National Interest vs. Online Freedom of Expression: The Discussions of Internet Users on the Blocking of 'Wikipedia' in Turkey". Etkileşim. 5. 10-22.

\begin{abstract}
In 2017, The Information and Communication Technologies Authority (ICTA) blocked online access to the online encyclopedia Wikipedia in Turkey due to its articles and comments that mention Turkey as a country that seems to be in coordination and aligned with various terrorist groups. Since then, the blocking has been criticized by Turkish people as a violation of the right of access to knowledge and a crackdown on online freedom of expression. However, freedom of expression becomes controversial when expression appears to threaten some important national interests. This paper aims at providing a framework for resolving questions about the recognition of online information rights, by finding out the rationale behind online users' arguments on freedom of expression. In this article, online users' comments on the blocking of Wikipedia in Turkey are analyzed. The findings reveal that most of the users disapprove the blocking. Both opponents and approvers discussed the issue by putting a broad framework and they put forward very different arguments to justify their attitude.
\end{abstract}

Keywords: online freedom of expression, disputed rights, users' comments, censorship. 


\title{
ULUSAL ÇIKARLAR VERSUS ONLINE IFADE ÖZGÜRLÜĞÜ: INTERNET KULLANICILARININ TÜRKIYE'DE 'WIKIPEDIA'NIN ENGELLENMESI ÜZERINE TARTIŞMALARI
}

\author{
Ruhdan UZUN*
}

Gönderim Tarihi: 15.01.2020 - Kabul Tarihi: 04.03.2020

Uzun, R. (2020). “National Interest vs. Online Freedom of Expression: The Discussions of Internet Users on the Blocking of 'Wikipedia' in Turkey". Etkileşim. 5. 10-22.

\section{Özet}

Bilgi Teknolojileri ve illetişim Kurumu 2017 yılında, Türkiye'yi çeşitli terör gruplarıyla iş birliği içinde gösteren makale ve yorumları nedeniyle çevrimiçi ansiklopedi Wikipedia'ya Türkiye'den çevrimiçi erişimi engelledi. O zamandan beri engelleme, Türk halkı tarafından, bilgiye erişim hakkının ihlali ve çevrimiçi ifade özgürlüğünün engellenmesi olarak eleştirilmektedir. Ancak bazı önemli ulusal çıkarları tehdit eder gibi algılandığı zaman, ifade özgürlüğü tartışmalı hale gelir. Bu makale, çevrimiçi kullanıcıların ifade özgürlüğü konusundaki argümanlarının dayandığı gerekçeyi ortaya çıkararak çevrimiçi enformasyon haklarının tanınmasıyla ilgili sorunları çözmek için bir çerçeve sağlamayı amaçlamaktadır. Bu amaçla, çevrimiçi kullanıcıların Wikipedia'nın Türkiye'de engellenmesi konusundaki yorumları analiz edilmiştir. Bulgular, kullanıcıların çoğunun engellemeyi onaylamadığını ortaya koymaktadır. Hem muhalifler hem de onaylayanlar, konuyu geniş bir çerçeve çizerek tartışmakta ve tutumlarını haklı çıkarmak için kendi içlerinde çok farklı argümanlar öne sürmektedirler.

Anahtar Kelimeler: çevrimiçi ifade özgürlüğü, tartışmalı haklar, kullanıcı yorumları, sansür. 


\section{Introduction}

International organizations and national governments across the world have endorsed freedom of expression as a basic human right in the United Nations' Universal Declaration of Human Rights since 1948. Also in 2012, the United Nations Human Rights Council adopted a landmark resolution affirming that 'the same rights that people have offline must also be protected online'. On the other hand, governments make greater efforts to restrict and control the use of the Internet for information and communication on political, moral, cultural, security, and other grounds. Along the same line, in 2017, national telecommunications regulatory and inspection authority of Turkey, The Information and Communication Technologies Authority (ICTA) blocked online access to all language editions of the online encyclopedia Wikipedia in Turkey because its articles and comments allege Turkey's involvement with terror groups. Since then, the blocking has been criticized by Turkish people as a violation of the right of access to knowledge and a crackdown on online freedom of expression.

This paper aims at providing a framework for resolving questions about the recognition of online information rights, by finding out the rationale behind online users' arguments on freedom of expression. To this end, the online users' comments on the blocking of Wikipedia in Turkey are analyzed. Such comments are a rich source of qualitative and quantitative data, which have the potential to increase our understanding of public opinions, and they provide insight into how attitudes and beliefs toward boundaries between censorship and information rights are formed as well as the nature of attitudes. Therefore, the findings of this study are based on quantitative and qualitative content analyses of 257 online users' comments on "Wikimedia Foundation urges Turkish authorities to restore access to Wikipedia" on the website of https://blog.wikimedia.org.

The study examines whether the users support the blocking, and which concepts they use while discussing the relationship between freedom of expression and national interests. Therefore, this paper contributes to the deliberation on disputed rights in order to improve online freedom of expression and access to knowledge.

\section{Freedom of Expression and Access to the Internet}

The concept of freedom of access to information is outlined in Article 19 of the UN Universal Declaration of Human Rights. Article 19 of the UDHR reads: "Everyone has the right to freedom of opinion and expression; this right includes freedom to hold opinions without interference and to seek, receive and impart information and ideas through any media and regardless of frontiers" (United Nations, n.d).

Several international conventions, including the aforementioned Universal 
Declaration of Human Rights and the International Covenant on Civil and Political Rights, seek to guarantee freedom of expression and the right of access to sources of information (Choldin, 1996). The idea on these declarations is that access to information allows citizens to participate in the democratic process and make informed choices that will lead to the development of society. If an individual's freedom of access to information or freedom of expression is impeded, the information flow suffers and democratic processes are set back. Freedom of expression is seen as essential to the creation and development of a democratic society.

In 2012 the United Nations Human Rights Council adopted a landmark resolution affirming that 'the same rights that people have offline must also be protected online' (MacKinnon, at all., 2015: 16). The Promotion, Protection and Enjoyment of Human Rights on the Internet (HRC 2012) calls on all states to promote and facilitate access to the Internet, and to ensure that the same rights of freedom of expression that are available offline are protected and upheld online (Carr, 2013: 61).

Despite the fact that freedom of expression is a fundamental human right, not all expressions are considered legal. Various interpretations of the freedom of expression can be found across the world. One promotes an "absolute freedom" or "liberal fundamentalism" seeing no limits to this freedom. Another "emphasizes tolerance, i.e. practising 'freedom with responsibility' or 'liberal pragmatism', taking other people's sensitivities into consideration, but still defending the right to full freedom of expression" (Eide and Naper, 2013: 188). It is crucial to state that (Hamilton and Ole Pors, 2003: 409):

Freedom of expression is a concept with limitations, not only accepted ones such as protection of individual's reputations, national security or issues of public safety, but also limitations put in place by more repressive authorities. Regimes that emphasize these exceptions can be found all around the World.

Dutton stated that freedoms of expression and connection to the Internet are not absolute in any cultural setting and this applies equally, whether considering expression online or offline (Dutton et al, 2010: 8). According to Emerson (1962: 878-879), the values sought by society in protecting the right to freedom of expression may be grouped into four broad categories. Maintenance of a system of free expression is necessary (1) as a means of assuring individual self-development, (2) as a means of attaining the truth, (3) as a method of securing participation by the members of society in social, including political, decision making, and (4) as a means of maintaining the balance between stability and change in the society.

Wicker and Santoso (2013: 44-45) remarked that these four categories are clearly connected to Internet access. (1) The Internet offers a wide variety of means for self-development through experimentation, discovery, and the testing of one's opinions and beliefs. (2) The Internet enables the search for truth by providing access to an unparalleled amount of information, from Wikipedia to a wide array of document archives; there is an immense amount 
of material at one's fingertips when one has access to the Internet. (3) The Internet is a marvelous means for securing participation. In this sense, the Internet has redefined the public sphere. With the advent of the Internet, information no longer flows in only one or two directions, but full circle and in multiple directions, promoting discussion, dialogue, and debate. (4) The balance to which Emerson alludes is attained by providing mechanisms for individuals to vent their frustrations and reactions to change in open fora. The Internet certainly provides ample opportunity for such expression. The Internet is clearly a means for advancing the values that buttress the rights status of freedom of expression.

\section{Blocking of "Wikipedia"in Turkey}

The right to freedom of opinion and expression covers the freedom to express and publish content as well as to have access to such content. As such, it provides for the right to press freedom and the right to information, and these apply across media platforms and national frontiers.

Freedom of information is an essential right for every person. It allows individuals and groups to protect their rights. It is an important guard against abuses, mismanagement and corruption. It can also be beneficial to governments themselves - openness and transparency in the decision-making process can improve citizen trust in government actions. On the other hand, governments make greater efforts to restrict and control the use of the Internet for information and communication on political, moral, cultural, security, and other grounds.

Along similar lines, Turkish Internet Regulator (ICTA) blocked online access to the online encyclopedia Wikipedia throughout Turkey on the grounds that its articles and comments describe Turkey's alleged involvement in terror groups. The blocking went into effect at 8:00 AM local time Saturday, April 29, 2017. In a written statement published on its website, The ICTA declared that "After technical analysis and legal consideration based on the Law Nr. 5651, an administrative measure has been taken for this website (wikipedia. org) according to Decision Nr. 490.05.01.2017.-182198 dated 29/04/2017 implemented by Information and Communication Technologies Authority".

According to what Anadolu Agency, Ahmet Arslan, Turkey's Transport, Maritime Affairs and Communications Ministry said, access has been blocked because the website hosted articles and comments that claimed Turkey was coordinating with terrorist groups. "Instead of coordinating against terrorism," the Ministry says, "it has become part of an information source which is running a smear campaign against Turkey in the international arena."

We want to have an interlocutor here and we want them to pay the appropriate tax to Turkey within our tax legislation by opening an office. They make an income from their publications in Turkey so we want them to be eligible to pay tax by open- 
ing an office here. This is another part of the problem,

Arslan concluded. According to the Ministry, the government asked Wikipedia to remove the content, which refused, leading to the ban. Wikipedia founder Jimmy Wales posted his response on Twitter, stating "access to information is a fundamental human right."

Turkish government complained about the content of two articles: on the Syrian war and on state-sponsored terrorism and demanded those to be removed. In meetings with the Turkish authorities, Wikipedia bosses explained that articles could be edited - and removing them contravened values of democratizing knowledge promoted by Wikipedia.

In March 2018, the Wikimedia Foundation launched their 'We miss Turkey' campaign, which calls for the block to be removed, and for people around the world to tweet how the block on Turkey has affected them. The Foundation is reprising the campaign this year on Twitter and Instagram. The campaign calls for the block to be removed and for people around the world to share how the block on Turkey has affected them.

Wikimedia Foundation Executive Board Chair Katherine Maher stated that they decided to appeal to the ECtHR after their applications to the supreme courts remained inconclusive.

The blocking has been criticized by Turkish people as a violation of the right of access to knowledge and a crackdown on online freedom of expression. As time went by, Turks have found ways to circumnavigate the block, using "mirror" Wikipedia URLs or Virtual Private Networks (VPN) to change their IP location.

\section{Method}

This paper aims at providing a framework for resolving questions about the recognition of online information rights, by finding out the rationale behind online users' arguments on freedom of expression. To this end, the online users' comments on the blocking of Wikipedia in Turkey are analyzed. Such comments are a rich source of qualitative and quantitative data that have the potential to increase our understanding of public opinions and they provide insight into how attitudes and beliefs toward boundaries between censorship and information rights are formed as well as the nature of attitudes. Therefore, the findings of this study are based on quantitative and qualitative content analyses of 257 online users' comments on "Wikimedia Foundation urges Turkish authorities to restore access to Wikipedia" on the website of https://blog.wikimedia.org. Content analysis is a research method for making replicable and valid inferences from data to their context, with the purpose of providing knowledge, new insights, a representation of facts and a practical guide to action (Krippendorff, 1980). 
The study examines whether the users support the blocking, and which concepts they use while discussing the relationship between freedom of expression and national interests. Therefore, this рарег contributes to the deliberation on disputed rights in order to improve online freedom of expression and access to knowledge.

\section{Findings and Comments}

The entire comment, which could consist of a simple phrase or several sentences, was treated as the unit of analysis. The comments were examined in three categories. These are: (1) "Internet users' responses to the blocking of Wikipedia in Turkey"; (2) "Users' target audiences" and (3) "the languages used by users".

\section{Internet users' responses to the blocking of "Wikipedia" in Turkey}

To determine the Internet users' responses to the blocking of Wikipedia in Turkey, the users' comments were identified as supportive, unsupportive or unclassifiable. As can be seen in Table 1, the findings of content analysis reveal that most of the users disapprove the blocking. Of the 257 comments, 136 (53\%) did not support the blocking while 88 comments were in support of it. 33 comments that were not related to the blocking were considered unclassifiable.

Table 1. Internet users' responses to the blocking of Wikipedia in Turkey

\begin{tabular}{|l|c|c|}
\hline Responses & Frequency & Percent \\
\hline Supportive & 88 & $34 \%$ \\
\hline Unsupportive & 136 & $53 \%$ \\
\hline Unclassifiable & 33 & $13 \%$ \\
\hline Total & $\mathbf{2 5 7}$ & $\mathbf{1 0 0 \%}$ \\
\hline
\end{tabular}

- Unsupportive comments:

As a result, although the majority of users opposed the blocking, the reasons were different from each other. Those who oppose the blocking argued that the blocking leads to ignorance; it hinders freedom, science and progress; the government left the society ignorant to be safe from criticism. For example;

Whatever the reason is, the closure of libraries is unacceptable for freedom, science and progress. (Star46656)

The aim of the government is to make the people ignorant. Nobody should try to mislead us with any propaganda. (batursoylu)

Administrators (the president) want to make people ignorant; they exploit our people and our country. (Bilinmeyen Kişi)

Opponents have described the blocking by referring to concepts such as

16 | ETKileşim | Yıl 3 Sayı 5 | Nisan 2020 
"the right to information", "freedom of the press", "the right to access to information" and "human rights". For example;

People have been denied their right to information. (Bu bir sansürdür)

Everyone has the right to access information and the Wiki is a free encyclopedia that everyone can benefit from. (Yazık)

Blocking the right of an entire country to access information is unthinkable. As soon as possible, this mistake should be reversed and Wikipedia unblocked. (Yiğit)

In any case, freedom of thought and ideas cannot be restricted. (herneyseiste)

This situation violates human rights. (Fatih Soydemir)

We are in the middle of a mistake again in terms of press freedom. (Orhan)

A user also referred to the Turkish Constitution:

One of the aims is to ensure that the Republic of Turkey also has the authority to freedom of citizens. To oppose this also means to contradict the fundamental principles of the Constitution. It is treason blocking platforms that contain ideas, contradict and criticize the government and to imprison people with these ideas. (Salih Umut Ulaş YÜKSEL)

The reasons the users who opposed the blocking gave were traces of the classical liberal understanding that the truth could be achieved with human wisdom and freedom instead of prohibitions. For example;

Preventing access to the site due to incorrect information, in fact, he is helpless in the face of the claim and accepts it. The human mind finds the right and the wrong, not the laws and prohibitions. The wiki should be opened. (Ali baba)

Only those who claim to defend the truth are those who are afraid to seek the truth; they do not tolerate opposing views. Who does not know the wrong can not know the truth. That's why we want the opening of the Wikipedia, which makes it easier for us to access information on almost everything. (hasan)

That's not the way to fight lies. Instead of lies, we can succeed by writing the truths and referring to them. (Emre)

It should also be noted that not all reviewers who do not approve the blocking should not be considered to have approved Wikipedia. Although some commentators oppose the government's ban, they find Wikipedia's position wrong. For example;

This is a shame on both sides! And for the one who prevents freedom, and for the other that take away others' freedom, saying 'I write what I want, I decide what is right and what is wrong'. (Metin)

As a result, both sides are faulty. The rights of the masses to learn and communicate have been violated. (Afrandez)

I am against the ban but I am sorry to see you cannot put the content in question here and explain that it is not a propaganda material as claimed. You can urge them but you should also check yourself. (M. Кага) 
Some commentators stressed that the ban on Wikipedia does not make sense because it targets the Turkish people. For example;

If there is a support to terrorism and shackle to Turkey, the way of fighting it is certainly not the access barrier. I cannot think of any logical explanation about what we intend to fight against by preventing the content written against us by ourselves.

The rest of the world can now access this content that we cannot access very easily and even when we are blocked, new content that will be created against us, which is really remote and biased, will be able to grow like a mountain outside the control of the Turkish people. (Кara Duman)

Some commentators described this as "punishing the Turkish people". For example;

While all the world access to the content that the government did not like, the Turkish people are actually punished by preventing access to Wikipedia. (Kadiritu@ yahoo.co)

When we close our eyes, will the rest of the world not be able to read these contents? That's nonsense:) It's nothing but self-punishment. (Erkin K.)

\section{- Supportive comments:}

In supportive comments on the blocking, it is argued that Wikipedia disseminates information that can be described as sided, disrespectful, incorrect and manipulable; it does not pay taxes in Turkey; it supports terror.

I'm sorry, but your freedoms end where someone else's freedom begins. (Adaletli Olun)

Freedom is a fact that every human being desires. But there is no such thing as unlimited freedom. Because where there is unlimited freedom, the freedom of others may also be violated. (Yalcin)

There is no uncontrollable freedom. Freedom is not about violating the rights of others, sharing inappropriate content, sharing articles that offend and humiliate the Turkish government and promote terror and terrorism. (Utku)

Commentators also discussed the nature of the information in Wikipedia. For example;

Wrong information is not information (mustafa)

Real information is not free but true. (metty)

Missing information is better than free and wrong information. (Emine Alkan)

The Republic of Turkey is a "FREE" country. Anyone can do whatever they want, as long as they don't hurt anyone. Situations that harm others cannot be defined as "FREEDOM". (Nihat)

Knowledge is freedom, right. But, don't be humiliated enough to consider lie and

18 | ETKíleşim | Yıl 3 |Sayı 5 | Nisan 2020 
slander as knowledge. (Bilge)

Give up to mention defamatory articles about Turkey as 'knowledge'. (Kamer)

It is not possible to consider a false phrase as information. (ilker GENCER)

If you don't present any biased information, it's free. You cannot prevent people's freedom to write accurate information. (Haters Gonna Hate)

I fully support this blocking. The sided publication cannot comply with freedom of information. (ilker Ayanoğlu)

Some commentators criticized Wikipedia's articles about terror. For example;

Obviously Wikimedia itself decides who is a terrorist organization and who supports terrorism. (...) It is unacceptable to say, 'We advocate free sharing of knowledge, to behave in this way, then to write ambiguous articles and manipulate society'. (Winston Smith)

You have no right to make my country bad and make terrorists legal. Even though I don't like the government, I support the ban unless you turn it wrong. (Kamil Sönmez)

It is important to note that a structure that emerged as an encyclopedia, like a media organ, has included terrorist propaganda. As in other platforms, 'freedom' was abused here. (auguste dupin)

If you defend your publications that show Turkey as a terrorist supporter instead of removing them, who does not get your publication ban. First, delete content that does not reflect the truth from your site, then fulfill the request of the Republic of Turkey. (ismail Altınok)

We love Wikipedia. Unless you support terrorism. You deserve to be shut down. I hope you return from your mistake. (Erol Mehmet Yıldız)

Some users argued that Wikipedia defames Turkey by disseminating incorrect, false, manipulative information; and misrepresent Turkey. For example;

We are not going to disregard our brothers and sisters who are victims of terrorism. Despite all this, there is a slander that Turkey still supports terrorism. (Erman)

There is no such situation in the conflict with the jurisdiction of the Republic of Turkey. In such a case, the state will have to use its sanction power.. (tts2)

Some users supported the blocking but opposed its form. For examples;

Although I consider this ban as rightful, Wikipedia's not all, I think that if Turkey blocks to access to the page accused of terrorism it would be more reasonable. (Aykut)

It is better if only unwanted titles are blocked. (Berkay Dursun)

\section{Target audiences of the users' comments}

The target audience of the users is important in determining the subject to which freedom of expression is directed. The target audience of the users 
is shown in Table 2. According to this, the majority of the comments addressed the general readership (72\%). The remaining comments addressed other commenters (2\%), Wikipedia (24\%) and The Government of Turkey (2\%).

Table 2. Users' target audiences

\begin{tabular}{|l|c|c|}
\hline Target audiences & Frequency & Percent \\
\hline General readership & 185 & $72 \%$ \\
\hline Special readership & 5 & $2 \%$ \\
\hline Wikipedia & 61 & $24 \%$ \\
\hline The Government of Turkey & 6 & $\mathbf{2} \%$ \\
\hline Total & $\mathbf{2 5 7}$ & $\mathbf{1 0 0 \%}$ \\
\hline
\end{tabular}

As can be seen in the figure above, most users have not segmented their target audience. Merely, a negligible number of users have used the forum to address Wikipedia managers or the government of Turkey.

\section{The languages used by users}

The language used by the users in their comments is shown in Table 3. Accordingly, 219 of the users (85\%) commented in Turkish. 29 User (11\%) left a comment in English. Only 9 users wrote comments in both Turkish and English. It can be said that users wrote in English (totally 15\%) want to reach larger audience.

Table 3. The languages used by users in their comments

\begin{tabular}{|l|c|c|}
\hline Languages & Frequency & Percent \\
\hline Turkish & 219 & $85 \%$ \\
\hline English & 29 & $11 \%$ \\
\hline Turkish + English & 9 & $4 \%$ \\
\hline Total & $\mathbf{2 5 7}$ & $\mathbf{1 0 0 \%}$ \\
\hline
\end{tabular}

It is thought that users who commented in English/English-Turkish want to convey their opinions to more people. Moreover, considering that not all users speak English, it is possible there is a higher proportion of users who want to appeal to the international public.

\section{Conclusion and Suggestions for Future Research}

The purpose of this paper was to provide a framework for resolving questions about the recognition of online information rights, by finding out the rationale behind online users' arguments about online freedom of expression. Con-

20 | ETKileşim | Yıl 3 |Sayı 5 | Nisan 2020 
tent analysis was conducted to evaluate publicly available users' comments on the blocking of Wikipedia in Turkey. The results of the content analysis show that the blocking of Wikipedia is not supported by most of the users on the grounds that online freedom of expression and freedom of access to knowledge are part of the general freedoms. However, this paper demonstrates that some users, even if they do not support the blocking, blame Wikipedia by claiming that Wikipedia restricts freedoms by not fulfilling requests of the Turkish government, and by disregarding Turkey's national interests. It is seen that some commentators perceive freedom of expression within international conventions and the constitutional framework and regarded the limitation of freedom on issues of national interest as normal. They argued that Wikipedia is abusing freedoms. However, most commentators who support the blocking advocated preventing access to articles and comments allege Turkey's involvement with terror groups instead of completely blocking of Wikipedia.

To understand how online users framed freedom of expression more detailed research is needed because upholding of freedom of expression is important to promote democratic culture.

\section{References}

Carr, M. (2013). "Internet Freedom, Human Rights and Power". Australian Journal of International Affairs. 67(5). 621-637.

Choldin, M. T. (1996). "Beginning a Conversation on Access to Information and Freedom of Expression". IFLA Journal. 22(4). 280-284.

Dutton, W. H., Dopatka, A., Hills, M., Law, G., Nash, V. (2010). "Freedom of Connection-Freedom of Expression: The Changing Legal and Regulatory Ecology Shaping the Internet". http://www.unesco.org/new/fileadmin/MULTIME$\mathrm{DIA} / \mathrm{HQ} / \mathrm{Cl} / \mathrm{Cl} / \mathrm{pdf} /$ wsis_igf5_executive_summary_freedom_expression. pdf.

Eide, E., Kjølstad, M., Naper, A. (2013). "After the 22 July Terror in Norway". Nordic Journal of Migration Research. 3(4). 2013. 187-196.

Emerson, T. I. (1962). "Toward a General Theory of the First Amendment". Yale Lj.

Hamilton, S. and Ole Pors, N. (2003). "Freedom of Access to Information and Freedom of Expression: The Internet as a Tool for Global Social Inclusion". Library Management. 24(8/9). 407-416.

Krippendorff, K. (1980). Content Analysis: An Introduction to Its Methodology. Newbury Park: Sage Publications.

MacKinnon, R., Hickok, E., Bar, A., Lim, H. I. (2015). Fostering Freedom Online: The Role of Internet Intermediaries. UNESCO Publishing. 
Madden, A., Ruthven I., McMenemy D. (2013). "A Classification Scheme for Content Analyses of Youtube Video Comments". Journal of Documentation. 69(5). 693-714.

United Nations. (n.d). The Universal Declaration of Human Rights . www.un.org/ en/documents/udhr.

Wicker, S. B. and Santoso, S. M. (2013). "Access to the Internet is a Human Right". Communications of the ACM. 56(6). 43-46.

Wikimedia Foundation. (n.d). Blog Wikimedia. https://blog.wikimedia.org.

22 | ETkileşim | Yıl 3 |Sayı 5 | Nisan 2020 